Jolanta Kruk

https://doi.org/10.26881/pwe.2020.50.01

ORCID: 0000-0001-9599-0446

Dolnośląska Szkoła Wyższa

jkruk@wsb.gda.pl

\title{
Uczenie się $w$ środowisku i dla środowiska jako wymóg współczesności
}

\section{Summary}

Learning in and for the environment as a contemporary prerequisite

The article discusses the methods of defining and describing the processes of learning in what is generally acknowledged as the learning environment. In the contemporary pedagogical discourse the category of the "learning environment" (formerly associated with the surroundings of school and the classroom) is always expanding and acquiring new meanings, in the wake of ecological changes and the virtualisation of contemporary culture. The "learning environment" becomes a part of the ongoing descholarisation, which manifests itself, for example, in the "open space" movement, outdoor education or "Gesamtschule", the trends related to the transfer of education outside of school. In the last part of the text, a postulate is formed to include a "learning for the environment" category to the pedagogical theory and practice. This stems from the need to deepen the social sensitivity of the threat of degradation of the entire ecosystem in which we live today.

Keywords: environment, learning, learning for the environment, learning environment, didactics, cultural change

Słowa kluczowe: środowisko, uczenie się, uczenie się dla środowiska, środowisko uczące, dydaktyka, zmiana kulturowa

\section{Wprowadzenie}

Środowisko naturalne - niegdyś postrzegane neutralnie jako zbiór wzajemnie powiązanych żywych organizmów, nieożywionych składników i ich otoczenia, tworzących złożone ekosystemy - obecnie stało się kategorią nasycaną nowymi znaczeniami o silnym zabarwieniu emocjonalnym. Często są to emocje negatywne (frustracja, gniew, bezsilność), związane z ujawnieniem skali niszczącego wpływu oddziaływań człowieka na biosferę. W ostatniej dekadzie nastąpiło gwałtowne przyspieszenie procesów zmieniających ziemską atmosferę, glebę, wody oraz faunę i florę. Procesy te, związane z globalną gospodarką, spowodowały naruszenie kruchej równowagi między poszczególnymi ekosystemami, czego efekty obszernie zostały opisane $\mathrm{w}$ raporcie Intergovernmental Panel on Climate Change (IPCC) z 2018 r. Ocena całego środowiska - zwłaszcza zmian klimatu oraz towarzyszących temu 
zjawisk - wskazuje na to, że zachodzi bezpośredni związek pomiędzy działalnością przemysłowo-ekonomiczną człowieka a stanem hydrosfery i atmosfery, poziomem zanieczyszczenia gleby, a w rezultacie - liczebnością poszczególnych gatunków roślin i zwierząt, sytuacją żywnościową, bezpieczeństwem energetycznym, dostępnością wody pitnej, zjawiskami migracji oraz wzrostem niepokojów społecznych. Współzależność tych zjawisk, wynikająca ze specyfiki wielkich ekosystemów, powoduje, że środowisko ludzkie z naukowo względnie neutralnej kategorii w ostatnich latach przekształciło się w politycznie zaangażowany konstrukt. Niepokojące jest podważanie wiarygodności i sensu naukowego dyskursu wokół wszystkich tych zjawisk, które w najbliższej przyszłości będą miały decydujące znaczenie dla życia gatunków naszej planety, z człowiekiem włącznie. Upolitycznienie takich kategorii, jak: środowisko, ekologia, zmiana klimatyczna, oznacza po pierwsze, że w sferze publicznej panuje powszechne przekonanie, że są one znaczące, po drugie zaś - iż uczestnicy życia społecznego odmiennie rozumieją te znaczenia. Różnorodność stanowisk jest cenną wartością $\mathrm{w}$ debacie, problem leży w niechęci wielu wpływowych członków społeczeństwa (polityków, samorządowców, liderów medialnych) do przyjęcia potwierdzonych badaniami faktów związanych ze zmianami w środowisku, jakie zaszły $\mathrm{w}$ fazie przyspieszenia przemysłowego ostatnich dekad. Już na wstępie rodzi to podstawowe trudności komunikacyjne, spowodowane odrzucaniem przez wielu uczestników życia społeczno-politycznego racjonalnej argumentacji zakorzenionej w wiedzy naukowej na rzecz gry politycznych, doraźnych interesów.

Każda krytyka decyzji skutkujących pogorszeniem stanu naszej biosfery (np. krytyka negowania konieczności osiągnięcia neutralności klimatycznej w najbliższych dekadach) może zostać przez niektórych potraktowana w kategoriach politycznych, podczas gdy w rzeczywistości - w opinii zwolenników racjonalnej i uzasadnionej empirycznie argumentacji - jest podyktowana troską o jakość życia i zdrowia przyszłych pokoleń. W tej sytuacji naturalną powinnością ludzi powiązanych ze sferą edukacji: pedagogów, nauczycieli i rodziców, samych uczniów, samorządowców i społeczników oraz wszystkich osób sfery publicznej jest pełne zaangażowanie na rzecz powstrzymania nadciągającej katastrofy klimatycznej. Ta powinność dla wszystkich świadomych zagrożenia osób staje się w dzisiejszych warunkach imperatywem, gdyż pomijanie lub zafałszowanie w procesie kształcenia (w debacie społecznej i mediach, niekiedy też w szkołach i na uczelniach) rzetelnej wiedzy na temat zjawisk zachodzących w naszym środowisku jest sprzeniewierzeniem się podstawowym nakazom etycznym związanym z profesją pedagoga.

Podejmując $\mathrm{w}$ artykule zagadnienie uczenia się w środowisku, nie można - w mojej opinii - pominąć zarysowanej problematyki, dlatego w jego końcowej części sformułowano propozycję wprowadzenia do języka pedagogiki terminu ,uczenie się dla środowiska” na oznaczenie aktywności związanej z zaznajamianiem się z aktualną wiedzą o zmianach w środowisku człowieka i kierunkach postulowanych działań w obszarze edukacji i aplikowaniem jej do praktyki pedagogicznej. W głównej części tekstu została przeprowadzona analiza różnych możliwości uczenia się w środowisku, dobrze utrwalonych w tradycji pedagogicznej. Próba uporządkowania tych wątków w odniesieniu do sfery edukacji rodzi 
jednak poczucie niedosytu; obecnie dla pedagogów jest bowiem istotne znalezienie formuły na to, co dzieje się w środowisku człowieka poza szkołą i instytucjami związanymi z kształceniem.

W odniesieniu do procesów kształcenia kategoria środowiska została przedstawiona w kilku aspektach. Jest ona określana jako:

- przestrzeń uczenia się powiązana ze szkołą i z klasą szkolną;

- otwarta lub zamknięta sfera oddziaływań edukacyjnych;

- pojęcie powiązane z kulturą, stylami uczenia się i nauczania, sposobami pracy dydaktycznej;

- kategoria związana z nowymi mediami i ich wykorzystaniem w pracy dydaktycznej;

- kategoria podlegająca ewolucji: od „środowiska uczącego” do „uczenia się dla środowiska".

\section{Uwagi terminologiczne: środowisko a środowisko uczące}

Środowisko jest pojęciem często pojawiającym się - poza naukami przyrodniczymi (biologia, geografia czy ekologia) - także w naukach społecznych. O ile w przyrodoznawstwie z tym określeniem łączy się problematykę związaną np. z opisami powietrza, gleby czy wody oraz ich specyfiką wynikającą z ingerencji człowieka, o tyle w przypadku nauk społecznych obejmuje ono kwestie cywilizacyjne i kulturowe w ujęciu środowiskowym (Umiński 1995: 214). W odniesieniu do świata społecznego kategoria środowiska i jego zaplecza zyskuje nowe znaczenia, związane z wzajemnymi interakcjami pomiędzy biologicznym a społecznym światem życia ludzi. Mówiąc o środowisku w kontekście życia społecznego, należy zwrócić uwagę, że specyficzny dla człowieka sposób istnienia i dostosowania się do życia w otoczeniu odbywa się z wykorzystaniem narzędzi, które stały się elementem dzisiejszej kultury, także w wymiarze symbolicznym.

Na pytanie o to, czym jest środowisko uczące, badacze udzielają odmiennych odpowiedzi w zależności od przyjętych założeń odnoszących się do rozumienia istoty procesu uczenia się. Istnieje wiele modeli środowiska uczącego, zależą one od paradygmatu dydaktycznego, czyli przyjętych założeń związanych ze stopniem aktywności i samodzielności uczących się, celów i treści kształcenia, poglądów na to, czym jest wiedza i jak tworzy ją człowiek (Klus-Stańska 2018: 42 i nn.). Wydaje się, że obecnie można wyróżnić co najmniej dwa znaczące ujęcia tej kategorii. W pierwszym środowisko uczące oznacza szkolne otoczenie ucznia wyzwalające: procesy poznawcze, komunikację w grupie i wszelkie celowe aktywności organizujące proces dydaktyczny. Elementami tego procesu są: uczeń, nauczyciel oraz wszystko to, co składa się na obudowę aktywności szkolnej. Opisywany model środowiska uczenia odwołuje się do założeń dydaktyki transmisyjnej z takimi elementami, jak: zamknięta przestrzeń dostosowana do przekazu treści nauczania, stały frontalny układ ławek i innych mebli szkolnych, wyeksponowana pozycja nauczyciela. 
W drugim ujęciu środowisko uczące oznacza zróżnicowaną i zmienną przestrzeń uczenia się, a jej organizacja ma na celu ułatwienie podmiotowi samodzielność działania, stawiania pytań, badania oraz podejmowania innych aktywności poznawczych. Procesy uczenia się, często tożsame z procesem badawczym, odbywają się w miejscach, w których stymulowana jest aktywność poznawcza. To tam zawarte są niezbędne zasoby, dające możliwość świadomego ich włączenia w strukturę profesjonalnego warsztatu pracy. Są to m.in. biblioteki, centra nauki i muzea, otwarte przestrzenie edukacyjne (parki tematyczne, ścieżki przyrodnicze, historyczne), stowarzyszenia i wolontariaty, laboratoria i pracownie.

\section{Środowisko uczące jako składnik kultury uczenia się}

Zasięg i możliwości międzyludzkiej komunikacji symbolicznej, odbywającej się we współczesnej kulturze, są obecnie niewyobrażalnie większe niż przed kilkudziesięciu laty. Jest to związane z rozwojem nowych technologii, robotyzacją produkcji, a przede wszystkim z rewolucją informacyjną - jej efektem jest wszechobecne wirtualne środowisko, w którym poruszamy się równolegle do realnego otoczenia naszego życia. W wyniku tych zmian proces uczenia się również uległ radykalnym przemianom. Obecnie przebiega on w odmiennych warunkach niż w środowisku definiowanym jako to, co otacza człowieka, wywiera na niego wpływ i podlega jego oddziaływaniom. Dawne rozumienie środowiska uczenia, obejmujące klasę wyposażoną w ławki i tablicę, obecnie w żaden sposób nie oddaje prawdziwego obrazu bogatego otoczenia, w którym się poruszamy, uczymy i badamy świat.

Odejście od wąskiego metodycznego rozumienia środowiska uczącego się sytuuje tę kategorię w nurcie filozofii kultury operującej wyjaśnieniami o charakterze interdyscyplinarnym i epistemicznym, a także poszerzeniem opisów podstawowych form aktywności uczącego się podmiotu, takich jak: eksplorowanie, eksperymentowanie, doświadczanie (Kruk 2014: 293). Współcześnie środowisko uczenia traktuje się jako kategorię społeczno-kulturową, ponieważ jest to nie tylko fizyczne miejsce, w którym odbywa się edukacja, lecz także cała złożona infrastruktura, do której należą:

- materialne środowisko dydaktyczne (klasy i pracownie, laboratoria, wyposażenie, meble szkolne, środki dydaktyczne);

- środowisko wirtualne (pracownie komputerowe, tablice interaktywne, programy i aplikacje, e-learning, blended learning i inne formy uczenia w sieci i grupach społecznościowych);

- społeczność szkolna/ucząca (uczniowie i ich rodzice, nauczyciele, członkowie stowarzyszeń edukacyjnych, grupy wsparcia zaangażowane w zmiany w szkole);

- środowisko formalne - administracja szkolna i władze oświatowe.

Teoretycy zgłębiający problematykę z zakresu dydaktyki zwracają uwagę, że jest to dyscyplina wieloparadygmatyczna, cechująca się wykorzystywaniem opisów procesów poznawczych i uczenia się oraz przywołująca te same fakty, ale w odmiennych kontek- 
stach interpretacyjnych w zależności od przyjętych uprzednio założeń cechujących dany paradygmat (Rubacha 2003: 63 i nn.; Klus-Stańska 2018: 42 i nn.). W odniesieniu do środowiska uczącego można zauważyć, że w poszczególnych grupach paradygmatów wyodrębnionych w dydaktyce istnieją zarówno różne, jak i wspólne cechy środowisk, w których przebiegają procesy poznawcze, oraz przestrzeni i aranżacji przyjętej dla procesu uczenia się. Niektóre elementy i cechy dominują, inne są prawie nieobecne w środowisku uczenia się ukształtowanym w danym paradygmacie. Zależnie od tego, jak są rozłożone akcenty odnoszące się do celów, programu i przebiegu procesu kształcenia, inaczej budowana jest jego infrastruktura. Duże znaczenie mają też atmosfera i stopień dominacji określonych czynności oraz aranżacja i wyposażenie pomieszczeń, w których ten proces przebiega, a także stopień wykorzystania mediów. Można zauważyć, że praktyka szkolna w ujęciu obiektywistycznym (paradygmat dydaktyki transmisyjnej) wyraźnie oddziela środowisko i przestrzeń szkolną od pozaszkolnego kontekstu. To, co szkolne, ma charakter obowiązujący, natomiast otoczenie pozaszkolne pełni funkcję dodatku do formalnej edukacji (Bruner 2006). Zupełnie inaczej rolę środowiska uczącego definiują pedagodzy zorientowani konstruktywistycznie. W ich koncepcjach uczenia środowisko jest rozumiane jako zmienne i dynamiczne zaplecze materialne i społeczne procesu uczenia się. W zasadzie wszystko, co otacza odbiorców oddziaływań edukacyjnych, w danej sytuacji może się stać środowiskiem uczącym, zależnie od kontekstu i sytuacji mającej potencjał wyzwalający aktywność poznawczą. Dla pedagogów krytycznych środowisko to swoista scena, na której rozgrywają się procesy spoleczne i polityczne zarazem, na niej odbywa się walka o dominację i władzę. Dydaktyczny potencjał środowiska jest zmienny i zależy od znaczeń, jakie nadają swemu otoczeniu uczący się i nauczający. Klasa szkolna może zatem być miejscem dorastania do samodzielności i emancypacji, a w innej sytuacji społecznej może być narzędziem walki o dominację i wywieranie wpływu. Uczący się, jako aktywni uczestnicy życia szkolnego, nie tylko nie akceptują jego reguł, lecz również kontestują zastaną rzeczywistość przez różne zachowania o charakterze rytuałów (McLaren 1993: 19 i nn.).

\section{Środowisko uczące jako znaczący składnik descholaryzacji, ruchu open space i outdoor education}

W poglądach badaczy i praktyków zajmujących się szkołą i jej funkcjami można też odnaleźć inne podejścia, skrajnie odmienne od ujęć klasycznych, postrzegających tę instytucję jako ważny element struktury społecznej. Chodzi o ruch descholaryzacji, powstały jako wyraz sprzeciwu wobec opresyjnej i różnicującej roli szkoły w społeczeństwie. Zwolennicy descholaryzacji uważali, że edukacja, jako proces odbywający się w przestrzeni publicznej, nie wymaga specjalnych instytucji i powinna się opierać na nieskrępowanej komunikacji wspólnoty uczących się i nauczających. Zdaniem Ivana Illicha charakter szkolnictwa jest opresyjny, dlatego jedyną właściwą drogą do uzyskania realnej zmiany społecznej nie jest odnowa systemu szkolnego, lecz jego likwidacja. Edukacja zatem powinna realizować inne niż dotychczas cele: 
- każdemu, kto chce się uczyć, w dowolnym momencie życia musi być zapewnione prawo do korzystania z zasobów informacji;

- każdy, kto chce się dzielić swoimi wiadomościami, jest upoważniony do wyszukiwania tych, którzy chcą się od niego uczyć;

- każdy, kto chce przedstawić jakąś kwestię ogółowi, powinien mieć okazję, by to zrobić (Illich 1976).

Już od XIX w. w wielu społeczeństwach powstawały zbliżone do descholaryzacji ruchy, które nie były tak radykalne, jak późniejsza koncepcja Illicha, niemniej postulowały odejście od modelu szkoły zamkniętej. Zwolennicy edukacji alternatywnej uznawali szkołę w tradycyjnym kształcie za przeżytek, proponując w jej miejsce rozszerzoną, otwartą koncepcję przestrzeni uczącej, w której mogą zachodzić swobodne interakcje. Następnie powstał ruch szkół open space, który rozwinął się w Stanach Zjednoczonych w latach 70. i 80 . XX w., obejmując około $21 \%$ szkół. Ich odpowiedniki pojawiły się szkołach europejskich, przyjmując zróżnicowaną postać. Szkoły open space posiadają zazwyczaj duże pomieszczenie, w którym nauczyciele prowadzą zajęcia z kilkoma grupami uczniów. W centrum znajduje się przestrzeń społeczna, czyli cluster. Idea szkół open space obecnie przedostaje się do świadomości uczestników procesu edukacji, na co duży wpływ ma zwiększająca się liczebność miejsc o charakterze edukacyjnym, które w wielu aspektach z powodzeniem zastępują szkołę, a ich nowoczesna i sprzyjająca uczeniu się aranżacja często jest silnym impulsem do zmiany myślenia o koncepcji szkoły. Przykładem takiego rozumienia roli środowiska uczącego są współczesne niemieckie Gesamtschule, szkoły silnie związane ze środowiskiem lokalnym i z instytucjami, takimi jak biblioteka, teatr, muzeum czy park tematyczny.

Charakteryzując środowisko uczące, nie można pominąć mało popularnego w Polsce zjawiska edukacji outdorowej, realizowanej dzięki potencjałowi edukacyjnemu zawartemu w najbliższym otoczeniu uczących się. Istotą tego modelu jest uczenie się w środowisku naturalnym uczestników, nawet pomimo zatracenia przez nie większości cech przynależnych zrównoważonemu rozwojowi przyrodniczego ekosystemu człowieka. W badaniach nad rozumieniem i sposobami wykorzystania założeń outdoor education w praktyce wczesnoszkolnej przez nauczycieli tego etapu kształcenia wskazuje się, że jest to ogromny, lecz wciąż niewykorzystany potencjał możliwości zmiany edukacyjnej (Michalak, Parczewska 2019). Renata Michalak i Teresa Parczewska w badaniach przeprowadzonych w 17 szkołach w zróżnicowanych środowiskach (wielkomiejskich, małych miastach i wiejskich) wskazują, że w badanych placówkach w niedostatecznym stopniu wykorzystane są takie metody, jak: ćwiczenia w terenie, prace ogrodowe, pomiary, eksperymenty i doświadczenia tak charakterystyczne dla edukacji outdoorowej. Jak podkreślają badani nauczyciele, wynika to z przyjętej kultury uczenia się, opierającej się na modelach transmisyjnych, słabo podatnych na rekonstrukcję rytmu pracy szkoły i utrudniających samodzielne i aktywne zajęcia terenowe w małych grupach (Michalak, Parczewska 2019: 138 i nn.). Jako dominującą formę aktywności na zewnątrz szkoły respondenci wymieniali spacery bądź wycieczki, w niewielkim odsetku zaznaczając merytoryczne formy pracy 
poza szkołą, jak np. projekty edukacyjne, gry terenowe i prace ogrodnicze (Michalak, Parczewska 2019: 135-136).

\section{Klasa szkolna jako środowisko uczące}

Badacze edukacji zwracają uwagę, że klasa, pełniąc funkcję socjalizacyjną, ma tak zorganizowaną przestrzeń, by ułatwić nauczycielowi kierowanie pracą uczniów, a także by jej aranżacja sprzyjała efektywności procesu dydaktycznego. Wprowadzenie zmiany w projektowanie klasy i całego budynku szkolnego jest trudne z kilku powodów. Po pierwsze w świadomości ludzi związanych z edukacją kształt szkoły jest mocno utrwalony przez tradycję oraz przekonania społeczne związane z funkcjami pełnionymi przez szkołę. Po drugie projektowanie elastycznej przestrzeni szkolnej wymaga odejścia od założeń o szkole jako obszarze zamkniętym i zredefiniowania nie tylko jej funkcji, ale również zmiany filozofii kształcenia, na co składają się takie elementy, jak: cele i treści kształcenia, sposoby pracy dydaktycznej nauczyciela oraz stopień samodzielności uczniów. Innym powodem braku szerszej skali innowacji w projektach szkół i przestrzeni wewnętrznej budynków jest niedocenianie przez uczestników życia społecznego znaczenia wpływu środowiska na zachowania i kreatywność młodych osób w nim żyjących. Tymczasem: „Stosunkowo łatwo jest wykazać, że w nowo projektowanych lub całkowicie zmodernizowanych budynkach szkolnych tkwi olbrzymi potencjał, którego wyzwolenie będzie już tylko zależało od samych uczestników procesu edukacji. A co zrobić ze szkołami, które trudno zaliczyć do środowisk atrakcyjnych, z przestrzeniami słabo przysposabiającymi do rozmowy i w dekoracjach zakłócających proces socjalizacji wtórnej?” (Dymnicka, Rozmarynowska 2006: 255).

Klasy tworzone zgodnie z ideą open space znacząco różnią się od klas opartych na modelu tradycyjnym. W miejsce monotonnych, podobnych do siebie sal lekcyjnych z rzędami ławek, biurkiem nauczycielskim i tablicą pojawiają się pomieszczenia zróżnicowane w zależności od celów, jakim służą, z widoczną dbałością o dobre wzornictwo i dostosowanie do fizycznych możliwości uczniów. Przykłady takich aranżacji coraz liczniej pojawiają się w rodzimych opracowaniach, ich autorzy zwracają uwagę na znaczenie projektowania fizycznej przestrzeni, w której przebywają uczniowie, dla ich aktywności indywidualnego stylu uczenia się. Marcin Polak, redagujący portal Edunews, opisuje i ilustruje następujące przykłady takich aranżacji, są to m.in.: „Media laby - to niewielkie sale przeznaczone dla kilku osób pracujących z wykorzystaniem urządzeń komputerowych. Studio - sala z wyciszonymi ścianami i drzwiami do zajęć taneczno-muzycznych. Samotne drzewo - miejsce spotkań, pozwalające przebywać i nawiązywać interakcje większej grupie uczniów. Wokół drzewa zaprojektowane miejsce do siedzenia «na trawie» lub na murku. Tu uczniowie swobodnie rozmawiają, nawiązują znajomości, dzielą się informacjami i pomysłami. Loże - miejsce rozmów w zespołach” (Polak 2016: 78).

Należy zauważyć, że takie samo wyposażenie i aranżacja klasy szkolnej jako miejsca edukacji mogą generować odmienne modele pracy dydaktycznej. Interaktywne tablice, 
tablety czy wielość środków dydaktycznych nie są też wystarczającym warunkiem otwartej komunikacji $\mathrm{w}$ trakcie procesu uczenia się, a niekiedy mogą utrwalać transmisyjny styl pracy nauczyciela. Bogate oprzyrządowanie dydaktyczne jest potrzebne, ale o powodzeniu określonego modelu pracy metodycznej decyduje splot wielu czynników, na które składają się: przyjęte cele i program edukacji, stopień samodzielności uczących się, struktura organizacyjna miejsca, w którym przebiega proces dydaktyczny, a także poglądy wyznawane przez nauczycieli odnośnie do tego, czym jest proces uczenia się i nauczania i jak powinien on przebiegać.

\section{Wirtualne środowisko uczące}

Współcześni badacze do środowiska uczącego zaliczają również tzw. rozszerzoną rzeczywistość, obejmującą: społeczności wirtualne i komunikację w sieci oraz czerpanie $\mathrm{z}$ zawartych w niej zasobów, a także korzystanie z różnorodnych form uczenia się na odległość z wykorzystaniem różnych mediów. Warto zauważyć, że dawniejsze określenie „nowe media” jest obecnie poszerzane o pojęcie „nowe nowe media”, oznaczające urządzenia mobilne z bogatym oprzyrządowaniem umożliwiającym stałe bycie w sieci i uczestniczenie równolegle w często więcej niż jednej wirtualnej społeczności. Współcześnie jest to typowy styl komunikowania się i życia społecznego nowej generacji.

Wykorzystanie mobilnych urządzeń $\mathrm{w}$ trakcie uczenia się może być oparte na włączeniu ich w tryb pracy laboratoryjnej (pomiary, rejestracja, odczyty). Obecnie smartfony i tablety są wyposażone w wiele specyficznych aplikacji, dzięki którym mogą służyć jako podręczne przyrządy pomiarowo-rejestracyjne przydatne w pracy laboratoryjnej. W 2013 r. opublikowano przeprowadzone w Uniwersytecie Gdańskim badania nad użytkowaniem mobilnych urządzeń przez najmłodsze pokolenie. Badania te, zatytułowane „M(obile) Mama”, dostarczyły danych wskazujących, że polskie dzieci w wieku przedszkolnym i wczesnoszkolnym są aktywnymi użytkownikami mobilnych urządzeń (najmłodszy użytkownik miał dziewięć miesięcy, najstarszy - dziewięć lat), a m(obile) matki dostrzegają $\mathrm{w}$ tych urządzeniach prorozwojowy potencjał i niezwykle chętnie włączają mobilne urządzenia w pole socjalizacyjne własnych dzieci (Bougsiaa i in. 2013). Aspekt ten warto rozważyć w odniesieniu do środowiska uczącego szkoły. Analiza pożądanych cech nauczyciela $\mathrm{w}$ środowisku wirtualnym prowadzi do stwierdzenia, że w warunkach komunikacji asynchronicznej relacje pomiędzy uczniami a nauczycielem stają się mniej formalne i hierarchiczne, a samo środowisko uczące nabiera przez to walorów aktywizujących (Juszczyk 2018: 148). Środowisko wirtualne okazuje się nie sprzyjać metodom podającym i biernej percepcji, ma natomiast potencjał sprzyjający interakcjom i współpracy w aktywnie i demokratycznie wykorzystywanej przestrzeni. Stawia to nowe wymagania nauczycielom - oprócz dotychczasowych kompetencji merytorycznych i zawodowych, równie istotne są cechy osobowości, związane z otwartym i nieautorytarnym stylem pracy dydaktycznej (Juszczyk 2018: 150). 


\section{Od środowiska uczącego do uczenia się dla środowiska}

We wstępie podkreślono konieczność powiązania refleksji pedagogicznej i praktyk edukacyjnych z wiedzą i aktywnością na rzecz podtrzymania kondycji wspólnego środowiska życia: człowieka i jego biosfery. W sytuacji zachodzących niekorzystnych zjawisk konieczne staje się poszerzenie obszaru zainteresowań pedagogiki i metodyk nie tylko poprzez stałą aktualizację dotychczasowej wiedzy o zmianach zachodzących w środowisku i włączanie nowych wątków do programów wszystkich poziomów i typów kształcenia. Znacznie pilniejszym zadaniem jest praca nad postawami ludzi wobec zachodzących zjawisk w przyrodzie i skutków związanych z globalną zmianą w środowisku naturalnym i jej efektach społecznych. Wydaje się, że można wypracować konsensus dotyczący najbardziej znaczących dla pedagogów zadań w ramach szeroko rozumianego projektu uczenia się dla środowiska przez nowe formy naszej obecności w sferze publicznej, niestandardowe inicjatywy wychodzące poza szkołę i dotychczasowe tradycje dydaktyczne. Pedagodzy - jak żadna inna profesja - mają wszelkie narzędzia do realizacji tych zadań w sferze publicznej. Są to:

- zadania związane ze zmianą sposobu korzystania z naturalnych zasobów, takich jak woda, energia, zasoby kopalne ${ }^{1}$;

- zadania dotyczące pogłębiania wiedzy w społeczeństwie na temat zmiany klimatycznej i jej skutków²;

- zadania odnoszące się do postaw wobec biosfery: zwierząt, roślin, przyrody nieożywionej. Szeroki zakres tych zadań obejmuje rozumienie zarówno współzależności zachodzących pomiędzy wszystkimi składnikami biosfery, jak i konieczności utrzymania między nimi równowagi. Jest to warunkiem wypracowania postawy empatycznej wobec środowiska, polegającej na tym, że człowiek nie tylko unika zawłaszczania i niszczenia innych ekosystemów niż własny, lecz troszczy się także o przetrwanie w dobrej kondycji gatunków zwierząt i roślin oraz zasobów przyrody³;

1 Rok 2013 został ogłoszony przez UNESCO Międzynarodowym Rokiem Współpracy w Dziedzinie Wody. W uzasadnieniu czytamy: „Przewidywany wzrost populacji świata z 7 do 9 miliardów w 2050 roku spowoduje dalszy wzrost zapotrzebowania na produkty rolnicze o około 20 procent, a także na energię elektryczną o około 60 procent. Wszystko to wiązać się będzie z jeszcze większym zapotrzebowaniem na wodę" (Polski Komitet ds. UNESCO 2013). Jak wykazuje się w raporcie opracowanym przez Międzyrządowy Zespół ds. Zmian Klimatu w 2018 r., prognozy te okazały się nadmiernie optymistyczne (por. Nauka o klimacie, https://naukaoklimacie.pl, 5.04.2017).

2 Źródeł wiedzy na temat zmiany klimatycznej jest bardzo dużo, jednak bez dobrego przygotowania oddzielenie wiarygodnych doniesień, faktów, teorii i hipotez od niedostatecznie ugruntowanych informacji i teorii jest trudne, toteż rola pedagogów jest nie do przecenienia. Dodatkowe wsparcie stanowią profesjonalnie przygotowane portale prowadzone przez wolontariuszy i stowarzyszenia przy współpracy z ludźmi nauki.

3 Wiedza zawarta w programach szkolnych i mediach, np. o segregacji odpadów, ochronie zagrożonych gatunków lub sposobach oszczędzania wody i produkowania zielonej energii, już nie wystarcza do utrzymania stanu równowagi. W sytuacji wylesiania, wysychania zbiorników wody, eksploatacyjnego modelu rolnictwa potrzebne są skoordynowane reakcje, dające szansę na solidarne zachowania wspólnot ludzkich wobec 
- pedagodzy są potrzebni także w działaniach systemowych związanych z podejmowaniem inicjatyw na rzecz jakości życia młodych pokoleń. Służą temu: możliwość szerokiej komunikacji (sieciowanie), akcje systemowe i znajomość technik wywierania wpływu na podmioty decydujące w sprawach związanych z kondycją biosfery.

Są to tylko wybrane wątki, zaznaczające się w narastającej fali działań zaangażowanych osób, organizacji, stowarzyszeń i wolontariuszy na rzecz utrzymania dobrej kondycji wspólnego środowiska przyrodniczo-społecznego. Podstawą skuteczności tych oddziaływań są dostęp do rzetelnych źródeł wiedzy, stała jej aktualizacja i inicjatywy zmieniające świadomość i postawy z obojętnych na krytyczne i zarazem zaangażowane. Zadania te są propozycją wstępną, swoistym zaproszeniem do debaty, wynikającym z przeświadczenia, że głos pedagogów jest obecnie niezwykle potrzebny i powinien wybrzmieć na wszystkich poziomach. Chodzi tu o zaangażowanie się w poprawę zastanej sytuacji i przeciwstawienie narastającym zagrożeniom przez współpracę z uczniami, młodzieżą i rodzicami. Równie znaczące są inicjatywy popularyzatorskie dla dorosłych, zwłaszcza w obszarach poza zasięgiem dotychczasowych oddziaływań edukacyjnych, co daje szansę na zmiany w świadomości wspólnoty i nadzieję na przyszłość.

\section{Literatura}

Bougsiaa H., Cackowska M., Kopciewicz L. (2013), Dzieci w kulturze cyfrowej. „Ars Educandi”, 10. Bruner J.S. (2006), Kultura edukacji. Kraków, Universitas.

Dymnicka M., Rozmarynowska K. (2006), Architektura szkoły i jej społeczne funkcje. W: M. Mendel (red.), Pedagogika miejsca. Wrocław, Wydawnictwo Dolnośląskiej Szkoły Wyższej.

Hojnacki L. (red.) (2013), Mobilna edukacja. (R)ewolucja w nauczaniu - poradnik dla osób uczacych się. Warszawa, Think Global sp. z o.o. https://edustore.eu/pliki/mobilna-edukacja-poradnik-dla-edukatorow.pdf, 5.04.2017.

Illich I. (1976), Społeczeństwo bez szkoły. Warszawa, PIW.

Juszczyk S. (2018), Rekonfiguracja społecznej roli nauczyciela w klasie wirtualnej. W: M. Tanaś, S. Galancik (red.), Cyberprzestrzeń - człowiek - edukacja. Mistrz i uczeń w cyberprzestrzeni. Kraków, Oficyna Wydawnicza „Impuls”.

Klus-Stańska D. (2018), Paradygmaty dydaktyki. Myśleć teoria o praktyce. Warszawa, Wydawnictwo Naukowe PWN.

Kruk J. (2014), Dezintegracja szkolnego środowiska oraz możliwości jego harmonizowania. W: D. Klus-Stańska (red), (Anty)edukacja wczesnoszkolna. Kraków, Oficyna Wydawnicza „Impuls".

McLaren P. (1993), Antystruktura oporu, przeł. E. Kiszkurno-Koziej. W: Z. Kwieciński (red.), Nieobecne dyskursy. Toruń, Wydawnictwo Uniwersytetu Mikołaja Kopernika.

Mendel M. (red.) (2006), Pedagogika miejsca. Wrocław, Wydawnictwo Dolnośląskiej Szkoły Wyższej.

groźby zniszczenia całego ekosystemu (por. działania takich organizacji, jak: Greenpeace, World Wide Fund for Nature, BirdLife International, Vegetarians International Voice for Animals (Viva!) i wielu innych). 
Michalak R., Parczewska T. (2019), (Nie)obecność „outdoor education” w kształceniu szkolnym. Lublin, Wydawnictwo Uniwersytetu Marii Curie-Skłodowskiej.

Polak M. (2016), Przestrzeń fizyczna i architektoniczna. T. 1: Przestrzenie edukacji 21. Otwieramy szkotę! Warszawa, Eduspaces21, https://edustore.eu/pliki/Przestrzenie-edukacji-tom1.pdf, 5.04.2017.

Polski Komitet ds. UNESCO (2013), Międzynarodowy Rok Wspólpracy w Dziedzinie Wody, 2013. http://www.unesco.pl/nauka/rok-wody-2013, 5.04.2017.

Rubacha K. (2003), Budowanie teorii pedagogicznych. W: Z. Kwieciński, B. Śliwerski (red.), Pedagogika. Podręcznik akademicki. T. 1. Warszawa, Wydawnictwo Naukowe PWN.

Umiński T. (1995), Ekologia, środowisko, przyroda. Warszawa, WSiP. 